\title{
Antidiabetic Aptitude of Cordia sebestena and its Outcome on Biochemical Parameters, Serum Electrolytes, and Hematological Markers
}

\author{
Sachin Chaudhary1,*, Harish Chandra Verma², Mandeep Kumar Gupta², Hitesh Kumar², Sudhansu Ranjan Swain², \\ Ramesh Kumar Gupta², Abdel-Nasser El-Shorbagi ${ }^{1,3}$
}

\section{Sachin Chaudhary ${ }^{1}$, Harish Chandra Verma ${ }^{2}$, Mandeep Kumar Gupta², Hitesh Kumar², Sudhansu Ranjan Swain ${ }^{2}$, Ramesh Kumar Gupta², Abdel-Nasser El-Shorbagi ${ }^{1,3}$}

'Department of Medicinal Chemistry, College of Pharmacy, University of Sharjah, UNITED ARAB EMIRATES.

${ }^{2}$ Department of Pharmaceutical Chemistry and Pharmaceutics, Moradabad Educational Trust, Group of Institutions, Faculty of Pharmacy, Uttar Pradesh, INDIA.

${ }^{3}$ Sharjah Institute for Medical Research, University of Sharjah, Sharjah, UNITED ARAB EMIRATES.

Correspondence

Dr. Sachin Chaudhary

College of Pharmacy, University of Sharjah, Sharjah, P.B. 27272,

United Arab Emirates.

Phone no: +971566311248

E-mail: sachin.nehra84@gmail.com

History

- Submission Date: 01-10-2018;

- Review completed: 15-11-2018;

- Accepted Date: 06-12-2018

DOI : 10.5530/pj.2019.11.65

Article Available online

http://www.phcogj.com/v11/i2

Copyright

(c) 2019 Phcog.Net. This is an openaccess article distributed under the terms of the Creative Commons Attribution 4.0 International license.

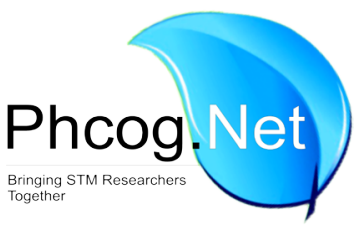

\begin{abstract}
Objective: The present study investigated the antidiabetic outcome of ethanolic extract of Cordia sebestena fruit (EECSF) in streptozotocin (STZ)-induced diabetogenic rodents and evaluated its consequence to improve the level of biochemical parameters, serum electroIytes level, and hematological indices along with its impact on body weight. Materials and Methods: The albino rodents were selected to observe oral glucose tolerance test by oral intake of aqueous glucose solution ( $4 \mathrm{~g} / \mathrm{kg}$, body weight) in normal rodents and assessment of blood glucose level after administration of EECSF at 100 and $200 \mathrm{mg} / \mathrm{kg}$ and standard drug glibenclamide at $0.6 \mathrm{mg} / \mathrm{kg}$, body weight. Antidiabetic activity was estimated in the chronic biological model by STZ (65 mg/kg/i.p.)-induced diabetes in rodents escorted by the determination of blood glucose. Further pharmacological research was carried out to explore the effect of EECSF on body weight, variations in biochemical parameters including aspartate aminotransferase, alanine aminotransferase, alkaline phosphatase, total bilirubin, and total protein, transformations in serum electrolytes such as $\mathrm{Na}^{+}, \mathrm{K}^{+}, \mathrm{Cl}^{-}$, and $\mathrm{Ca}^{2+}$ along with estimation of hematological indices such as red blood cells, white blood cells, hemoglobin, lymphocytes, neutrophils, eosinophils, and monocytes. Results: It was discovered that EECSF significantly lowered the blood glucose level of diabetic rodents along with enhancement in body weight. Correspondingly, EECSF significantly ameliorated the biochemical parameters, serum electrolytes, and hematological indices. Conclusion: The results demonstrated the antidiabetic potential of EECSF in STZ-induced diabetes in rodents, and it could be selected to benefit from diabetes and its affiliated complexities inclusive of anemia, diabetic nephropathy, retinopathy, neuropathy, and hepatitis.

Key words: Anemia, antidiabetic, Cordia sebestena, Glucose, Streptozotocin
\end{abstract}

\section{INTRODUCTION}

Diabetes is a metabolic disorder which evolves from imperfect insulin action and secretion. ${ }^{1}$ In congruence with the International Diabetes Federation, diabetes is among the utmost gigantic health hassles. The planetary preponderance of hyperglycemic patients is hypothesized to augment from 415 million in 2015 to 642 million by 2040 , symbolizing the escalation of $35.5 \%$ in the next 25 years. ${ }^{2}$ Diabetes inaugurates multiple organ ruination including eyes, kidneys, liver, heart, and blood vessels. ${ }^{3}$ Conventionally, blood investigation is one of the screening proceedings to authenticate general health. Glucose, cholesterol, calcium, total protein, alkaline phosphates, uric acid, sodium, potassium, and chloride levels are indicative values for diabetes mellitus ${ }^{4}$ and its associated diseases such as coronary artery disease, dyslipidemia, ${ }^{5]}$ diabetic nephropathy, ${ }^{6}$ chronic hepatopathy, and liver disease. $^{7}$ Innumerable plants are affluent source of antidiabetic consequence and have been practiced in traditional folk medicine for inversing hyperglycemia, ${ }^{8}$ and innumerable plant derived antidiabetic drugs have obtained authorization from WHO. ${ }^{9}$

Cordia sebestena (L.) (Boraginaceae) is universally recognized as Geiger tree. It comprises furthermore 300 species allocated extensively in East Africa, Mexico, West Indies, Central America, Sri Lanka, India, and Nigeria. Ethnomedicinally, the leaves are used as emollient and in the treatment of bronchitis, cough, fever, and influenza. The plant leaves showed antidiabetic and antibacterial activity. Sebestenoids A-D have been isolated from the fruits of C. sebestena and represented activity against Alzheimer's disease by inhibiting aspartic protease. ${ }^{10,11}$ The current research proposed antidiabetic potential of ethanolic extract of C. sebestena fruit (EECSF) employing streptozotocin (STZ) executed diabetes in rodents along with its influence on biochemical parameters, serum electrolytes level, and hematological markers. 


\section{MATERIALS AND METHODS}

\section{Chemicals}

All the chemicals used were of LR grade, purchased from Qualigens Fine Chemicals, Mumbai, India.

\section{Fruit collection and authentication}

The fresh and matured fruits were collected from the roadside garden of College of Pharmacy, University of Sharjah, Sharjah, United Arab Emirates. Prof. Sudhansu Ranjan Swain, Director, Department of Pharmacognosy, Moradabad Educational Trust, Group of Institutions, Faculty of Pharmacy, Moradabad, Uttar Pradesh, India, attained identification and authentication.

\section{Fruit extraction}

The freshly collected fruits ( $500 \mathrm{~g}$ ) of C. sebestena were dried and powdered at room temperature $\left(24^{\circ} \mathrm{C}-28^{\circ} \mathrm{C}\right)$. The powdered plant material was macerated with petroleum ether; the marc was exhaustively extracted with of ethanol for 3 days. The extract was dried by rotator evaporator (Buchi, U.S.A) under reduced pressure and procured in desiccator and the extract achieved was subjected to biological exploration.

\section{Animals}

Albino rodents (150-200 g) of either sex were nominated for pharmacological study. The animals were settled under standard environmental surroundings and provided with food and water ad libitum. The animals were put on starving for $12 \mathrm{~h}$ before the investigation, and study protocols were in conformity with proceedings authorized by the institutional animal ethics committee of Moradabad Educational Trust, Group of Institutions, Faculty of Pharmacy, Moradabad, Uttar Pradesh, India

\section{Acute toxicity study}

The acute toxicity of EECSF was evaluated at doses of 5, 50, 300, 500, and $2000 \mathrm{mg} / \mathrm{kg}$, as per the OECD 423 guideline, and dose of $2000 \mathrm{mg} / \mathrm{kg}$ represented toxic indications. Therefore, in agreement with OECD guideline 423 , it is expressed as a $\mathrm{LD}_{50}$ cutoff value. Doses, 100 and 200 $\mathrm{mg} / \mathrm{kg}$, bodyweight were preferred for pharmacological inspection by fixed-dose methods. ${ }^{12}$

\section{Assembling of animals for antidiabetic studies}

Experimental rodents were categorized into five groups $(n=6)$. Group-I (normal control) was administered with distilled water $(0.5 \mathrm{~mL} / \mathrm{kg}$, body weight, p.o.). Group-II (diabetic control) was administered with $5 \%$ Tween, p.o., Group-III permitted $0.6 \mathrm{mg} / \mathrm{kg}$, body weight of glibenclamide p.o., and Group IV-V permitted $100 \mathrm{mg} / \mathrm{kg}$ and $200 \mathrm{mg} / \mathrm{kg}$, body weight, p.o., of EECSF, respectively.

\section{Antidiabetic studies}

\section{Oral glucose tolerance test in normal rodents}

The normal rodents were fasted overnight to inspect oral glucose tolerance test and were divided into four groups $(n=6)$. Group-I (normal control) was provided with distilled water orally, Group-II (positive control) was provided with glucose $(4 \mathrm{~g} / \mathrm{kg})$ body weight. Group-III was administered with glibenclamide ( $10 \mathrm{mg} / \mathrm{kg}$, body weight, p.o.). Group-IV and $\mathrm{V}$ were treated with 100 and $200 \mathrm{mg} / \mathrm{kg}$, body weight, p.o., of EECSF, respectively, $30 \mathrm{~min}$ before the oral administration of glucose $(2 \mathrm{~g} / \mathrm{kg})$ body weight. Blood was collected from the tail at $0,30,60$, and $90 \mathrm{~min}$ intervals for estimation of glucose level.

\section{Experimental inception of diabetes}

Albino rodents (150-200 g) body weights were selected for the biological activity. Food was terminated $18 \mathrm{~h}$ before administration of STZ. STZ 65 $\mathrm{mg} / \mathrm{kg}$, body weight in ice-cold sodium citrate buffer $(0.01 \mathrm{~mol} / \mathrm{L}$ and $\mathrm{pH}$ 4.4) was injected intraperitoneally. Diabetes was affirmed by estimating fasting glucose level on the $2^{\text {nd }}$ day postadministration of STZ and rodents with glucose level elevated than $200 \mathrm{mg} / \mathrm{dL}$ were assigned as diabetogenic. ${ }^{13}$

\section{Biological study on streptozotocin-induced diabetic rodents}

The biological study was performed on animal groups by providing EECSF and standard drug for 21 days sequentially. The animals were fasted $18 \mathrm{~h}$ before processing for study and blood glucose levels were estimated on (considered as 0 day reading) 7, 14, and 21 days. The impact of EECSF at dose of 100 and $200 \mathrm{mg} / \mathrm{kg}$ along with glibenclamide at dose of $0.6 \mathrm{mg} / \mathrm{kg}$, on body weight was estimated on $7^{\text {th }}, 14^{\text {th }}$, and $21^{\text {st }}$ day.

\section{Assessment of body weight}

The body weight of the animals was measured at 0 day and every $7^{\text {th }}$ day for the period of 21 days.

\section{Blood collection and estimation of biochemical parameters}

On $21^{\text {st }}$ day, rodents were starved overnight and sacrificed by cervical decapitation and blood was assembled. For serum samples, blood was coagulated followed by centrifugation at $3000 \mathrm{rpm}$ for $20 \mathrm{~min}$ at $4^{\circ} \mathrm{C}$ to separate serum. Sera were divided in aliquots and maintained at $-80^{\circ} \mathrm{C}$ for biochemical assay. Fasting serum glucose level was estimated by glucose oxidase-peroxidase method employing kit of Randox Laboratories Ltd, U.K. Aspartate aminotransferase, alanine aminotransferase, and alkaline phosphatase (ALT, AST, and ALP) were assessed using standard kits supplied by Teco Diagnostics, U.S.A. Total bilirubin (TB) in the serum was estimated using commercial kit supplied by Human Diagnostics, Germany, and total protein (TP) was evaluated by method designed by Lowry et al. ${ }^{14}$

\section{Estimation of serum electrolytes}

To assess the effect of diabetes on serum electrolytes, $\mathrm{Na}^{+}, \mathrm{K}^{+}, \mathrm{Cl}^{-}$, and $\mathrm{Ca}^{2+}$ were estimated. ${ }^{15}$

\section{Estimation of hematological indices}

Red blood cells (RBCs), white blood cells (WBCs), hemoglobin ( $\mathrm{Hb}$ ), lymphocytes, neutrophils, eosinophils, and monocytes were estimated employing hematology analyzer SB21, New Delhi, India.

\section{Statistical analysis}

The data achieved were investigated to statistical analysis using one-way analysis of variance followed by Newman-Keuls test employing GraphPad Prism version 5.01, Graph-Pad software, San Deigo, California, U.S.A. The values were represented as mean \pm standard error of the mean for six rodents.

\section{RESULTS}

\section{Ethanolic extract of Cordia sebestena fruit dose election}

$\mathrm{LD}_{50}$ was estimated following the OECD guidelines to fix the dose for pharmacological screening. In this study, it was contemplated that up to a maximum dose of $2000 \mathrm{mg} / \mathrm{kg}$ body weight, there were no alterations in normal behavioral format and no prodromal of toxicity and mortality were observed. The pharmacological assessment was accomplished at doses of 100 and $200 \mathrm{mg} / \mathrm{kg}$ body weight. 


\section{Oral glucose tolerance test in normal rodents}

The significant demotion in blood glucose level (145.2 \pm 0.85 and $84.3 \pm$ $0.4 ; P<0.01$ and 0.05$)$ was perceived for ethanolic extract $(100 \mathrm{mg} / \mathrm{kg})$ at 60 and $90 \mathrm{~min}$ as compared to the animals in positive control group $(148.2 \pm 0.9$ and $138.0 \pm 0.56)$. The same extract at $200 \mathrm{mg} / \mathrm{kg}$ has more significantly reduced the blood glucose level to $81.5 \pm 0.7, P<0.05$ at 90 min compared to positive control group. Glibenclamide demonstrated its potent hypoglycemic effect by downgrading the elevated glucose level to almost normal level $(92.5 \pm 0.54$ and $82.6 \pm 0.5 ; P<0.05)$ compared to positive control group at 60 and $90 \mathrm{~min}$, respectively. The results are represented in Table 1.

\section{Biological study on streptozotocin-induced diabetic rodents}

The biological study was executed for 21 days on STZ-induced diabetic rodents, and its results are tabulated in Table 2 . EECSF at dose of $200 \mathrm{mg} / \mathrm{kg}$ indicated minimization of $33.16 \%$ and $32.39 \%$ in blood glucose level on the $14^{\text {th }}$ day and $21^{\text {st }}$ day $(P<0.001)$, respectively. It was also explored that glibenclamide reduced $40.12 \%$ and $53.93 \%$ in blood glucose level on the $14^{\text {th }}$ and $21^{\text {st }}$ day $(P<0.001)$.

\section{Consequence of ethanolic extract of Cordia sebestena fruit on body weight in diabetic rodents}

The body weight of rodents at different time intermissions during the study is entitled in Table 3. The percentage change in body weight of rodents for all groups was computed. Group-I (-ve control) revealed elevation of $3.7 \%$ in body weight. Group-II (+ve control) expressed reduction of $10.3 \%$ in body weight. Group-III, IV, and V represented $2.85 \%, 0.41 \%$, and $1.89 \%$ enhancement in body weight. Hence, it is affirmed that EECSF is effectual in restricting weight loss due to diabetes.

\section{Outcome of ethanolic extract of Cordia sebestena fruit on biochemical parameters}

The level of ALP, ALT, AST, and TB was intensified in Group-II (+ve control) by $80.5 \%, 115.79 \%, 104.58 \%$, and $262.5 \%$ although TP level was downturn by $39.04 \%$ compared to Group-I (-ve control) rodents. EECSF at 100 and $200 \mathrm{mg} / \mathrm{kg}$ dose subsided the level of ALP by $5.41 \%, 19.76 \%$; ALT by $10.09 \%, 27.03 \%$; AST by $20.72 \%, 29.76 \%$; and TB by $10.34 \%$, $34.48 \%$, whereas TP level was ascended by $35.4 \%$, $19.79 \%$, respectively. However, glibenclamide declined ALP by $34.99 \%$, ALT by $49.05 \%$, AST by $45.06 \%$, and $\mathrm{TB}$ by $58.62 \%$ and increased $\mathrm{TP}$ level by $1.82 \%$ as

Table 1: Consequence of ethanolic extract of Cordia sebestena fruit on oral glucose tolerance test in normal rodents

\begin{tabular}{|c|c|c|c|c|}
\hline \multirow[t]{2}{*}{ Groups } & \multicolumn{4}{|c|}{ Blood glucose level (mg/dL) } \\
\hline & $0 \mathrm{~min}$ & $30 \mathrm{~min}$ & $60 \mathrm{~min}$ & $90 \mathrm{~min}$ \\
\hline Group-I (negative control) & $82.3 \pm 0.45$ & $84.0 \pm 0.35$ & $82.0 \pm 0.9$ & $81.3 \pm 0.7$ \\
\hline Group-II (positive control) & $84.3 \pm 0.5$ & $122.0 \pm 0.9$ & $148.2 \pm 0.9$ & $138.0 \pm 0.56$ \\
\hline Group-III & $83.6 \pm 0.6^{*}$ & $94.8 \pm 0.9^{* * *}$ & $92.5 \pm 0.54^{\star * *}$ & $82.6 \pm 0.5^{\star * *}$ \\
\hline Group-IV & $83.0 \pm 0.4^{* * *}$ & $119.6 \pm 0.5^{* * *}$ & $145.2 \pm 0.85^{\star *}$ & $84.3 \pm 0.4^{* * *}$ \\
\hline Group-V & $81.7 \pm 0.3^{* *}$ & $101.5 \pm 0.4^{*}$ & $131.5 \pm 0.6^{*}$ & $81.5 \pm 0.7^{\star * *}$ \\
\hline
\end{tabular}

Values are mean \pm SEM; $n=6 ;{ }^{\star} P<0.001 ;{ }^{*} P<0.01 ;{ }^{* *} P<0.05$ compared with positive control. SEM: Standard error of mean

Table 2: Consequence of ethanolic extract of Cordia sebestena fruit on blood glucose levels in streptozotocin-induced diabetes in rodents

\begin{tabular}{|c|c|c|c|c|}
\hline \multirow[t]{2}{*}{ Groups } & \multicolumn{4}{|c|}{ Blood glucose level (mg/dL) } \\
\hline & 0 Day & 7 Days & 14 Days & 21 Days \\
\hline Group-I (negative control) & $85.5 \pm 2.5$ & $85.4 \pm 3.21$ & $88.60 \pm 2.6$ & $89.5 \pm 2.1$ \\
\hline Group-II (positive control) & $220.4 \pm 3.2$ & $261.5 \pm 3.4$ & $283.1 \pm 3.1$ & $265.5 \pm 3.2$ \\
\hline Group-III & $201.4 \pm 3.4^{\star}$ & $168.6 \pm 2.8^{\star * *}$ & $169.5 \pm 3.5^{*}$ & $122.3 \pm 3.4^{\star}$ \\
\hline Group-IV & $217.6 \pm 4.2(\mathrm{NS})$ & $246.5 \pm 4.3^{\star *}$ & $221.6 \pm 3.6^{*}$ & $201.5 \pm 3.1^{*}$ \\
\hline Group-V & $206.5 \pm 3.7^{\star * *}$ & $198.6 \pm 3.4^{* * *}$ & $189.2 \pm 3.4^{*}$ & $179.5 \pm 3.4^{*}$ \\
\hline
\end{tabular}

Values are mean \pm SEM; $n=6 ;{ }^{\star} P<0.001 ;{ }^{* *} P<0.01 ;{ }^{* * *} P<0.05$ compared with positive control. SEM: Standard error of mean; NS: Nonsignificant

Table 3: Consequence of ethanolic extract of Cordia sebestena fruit on body weight in streptozotocin-induced diabetes in rodents

\begin{tabular}{|c|c|c|c|c|}
\hline \multirow[t]{2}{*}{ Groups } & \multicolumn{4}{|c|}{ Body weight (g) } \\
\hline & 0 day & 7 days & 14 days & 21 days \\
\hline Group-I (negative control) & $171.6 \pm 0.6$ & $173.3 \pm 0.4$ & $178.3 \pm 0.8$ & $178.2 \pm 0.6$ \\
\hline Group-II (positive control) & $167.3 \pm 0.8$ & $165.2 \pm 0.7$ & $155.6 \pm 0.6$ & $151.6 \pm 0.3$ \\
\hline Group-III & $170.3 \pm 0.9^{* * *}$ & $175.3 \pm 0.9^{* * *}$ & $176.6 \pm 0.7^{* * *}$ & $175.3 \pm 0.7^{* * *}$ \\
\hline Group-IV & $169.6 \pm 0.6^{* *}$ & $167.2 \pm 0.7^{*}$ & $161.3 \pm 0.6^{* * *}$ & $170.3 \pm 0.4^{* * *}$ \\
\hline Group-V & $171.3 \pm 0.5^{\star}$ & $172.3 \pm 0.5^{* * *}$ & $171.5 \pm 0.5^{\star * *}$ & $174.6 \pm 0.3^{* * *}$ \\
\hline
\end{tabular}

Values are mean \pm SEM; $n=6 ;{ }^{\star} P<0.001 ;{ }^{* *} P<0.01 ;{ }^{* * *} P<0.05$ compared with positive control. SEM: Standard error of mean 
Table 4: Consequence of ethanolic extract of Cordia sebestena fruit on serum enzymes and biochemical parameters in streptozotocin-induced diabetes in rodents

\begin{tabular}{cccccc}
\hline Groups & ALP (IU/L) & ALT (IU/L) & AST (IU/L) & TB (mg/dL) & TP (g/L) \\
\hline Group-I (negative control) & $95.7 \pm 2.1$ & $78.50 \pm 2.0$ & $124.3 \pm 2.4$ & $0.8 \pm 0.01$ & $6.3 \pm 0.01$ \\
Group-II (positive control) & $172.75 \pm 2.4$ & $169.4 \pm 2.1$ & $254.3 \pm 2.6$ & $2.9 \pm 0.08$ & $3.84 \pm 0.03$ \\
Group-III & $112.30 \pm 1.3^{*}$ & $86.30 \pm 2.6^{*}$ & $139.7 \pm 3.2^{*}$ & $1.2 \pm 0.06^{*}$ & $3.91 \pm 0.06^{*}$ \\
Group-IV & $163.4 \pm 2.1^{* *}$ & $152.3 \pm 2.5^{*}$ & $201.6 \pm 2.9^{*}$ & $2.6 \pm 0.04^{* *}$ & $5.2 \pm 0.08^{*}$ \\
Group-V & $138.6 \pm 2.1^{*}$ & $123.6 \pm 2.7^{*}$ & $178.6 \pm 3.2^{*}$ & $1.9 \pm 0.03^{*}$ \\
\hline
\end{tabular}

Values are mean \pm SEM; $n=6 ;{ }^{\star} P<0.001 ;{ }^{\star \star} P<0.01 ; P<0.05$ compared with positive control. SEM: Standard error of mean; ALP: Alkaline phosphate; ALT: Alanine aminotransferase; AST: Aspartate aminotransferase; TB: Total bilirubin; TP: Total protein

Table 5: Consequence of ethanolic extract of Cordia sebestena fruit on serum electrolytes concentrations in streptozotocin-induced diabetes in rodents

\begin{tabular}{ccccc}
\hline Groups & $\mathrm{Na}^{+}(\mathrm{mEq} / \mathrm{L})$ & $\mathrm{Cl}^{-}(\mathrm{mEq} / \mathrm{L})$ & $\mathrm{K}^{+}(\mathrm{mEq} / \mathrm{L})$ & $23.5 \pm 0.01$ \\
\hline Group-I (negative control) & $148.3 \pm 1.2$ & $4.7 \pm 0.01$ & $19.5 \pm 0.03$ & $7.1 \pm 0.03$ \\
Group-II (positive control) & $123.5 \pm 2.1$ & $6.9 \pm 0.02$ & $22.6 \pm 0.05^{*}$ & $7.9 \pm 0.09$ \\
Group-III & $142.6 \pm 2.2^{*}$ & $5.2 \pm 0.06^{* * *}$ & $20.4 \pm 0.06^{*}$ & $8.04 \pm 0.03^{*}$ \\
Group-IV & $132.5 \pm 2.1^{*}$ & $6.7 \pm 0.06^{* *}$ & $21.2 \pm 0.07^{*}$ & $8.1 \pm 0.07^{*}$ \\
Group-V & $139.5 \pm 2.8^{*}$ & $5.4 \pm 0.08^{*}$ & \\
\hline
\end{tabular}

Values are mean \pm SEM; $n=6 ;{ }^{*} P<0.001 ;{ }^{* *} P<0.01 ;{ }^{* *} P<0.05$ compared with positive control. SEM: Standard error mean

Table 6: Consequence of ethanolic extract of Cordia sebestena fruit on hematological indices in streptozotocin-induced diabetes in rodents

\begin{tabular}{|c|c|c|c|c|c|}
\hline \multirow[t]{2}{*}{ Hematological indices } & \multicolumn{5}{|c|}{ Groups } \\
\hline & Group-I (negative control) & Group-II (positive control) & Group-III & Group-IV & Group-V \\
\hline $\mathrm{RBC}\left(\times 10^{6} / \mu \mathrm{L}\right)$ & $7.19 \pm 0.03$ & $4.35 \pm 0.05$ & $6.9 \pm 0.05^{*}$ & $4.57 \pm 0.03^{* *}$ & $6.4 \pm 0.07^{*}$ \\
\hline $\mathrm{WBC}\left(\times 10^{3} / \mu \mathrm{L}\right)$ & $14.5 \pm 021$ & $10.25 \pm 0.2$ & $11.87 \pm 0.6^{*}$ & $13.2 \pm 0.8^{* *}$ & $14.60 \pm 0.7^{*}$ \\
\hline $\mathrm{Hb}(\mathrm{g} / \mathrm{dL})$ & $13.1 \pm 0.02$ & $9.8 \pm 0.03$ & $12.3 \pm 0.04^{*}$ & $10.10 \pm 0.06^{*}$ & $11.89 \pm 0.05^{*}$ \\
\hline Lymphocytes (\%) & $23.5 \pm 0.6$ & $35.6 \pm 0.7$ & $22.6 \pm 0.7^{*}$ & $33.4 \pm 0.2^{* *}$ & $21.6 \pm 0.2^{*}$ \\
\hline Neutrophils (\%) & $46.3 \pm 0.6$ & $54.90 \pm 0.9$ & $47.6 \pm 0.7^{\star}$ & $50.4 \pm 0.6^{* * *}$ & $49.5 \pm 0.3^{* *}$ \\
\hline Eosinophils (\%) & $2.36 \pm 0.02$ & $4.1 \pm 0.03$ & $2.98 \pm 0.04^{*}$ & $3.9 \pm 0.04^{* *}$ & $3.01 \pm 0.07^{*}$ \\
\hline Monocytes (\%) & $4.19 \pm 0.03$ & $6.89 \pm 0.05$ & $4.96 \pm 0.08^{*}$ & $6.04 \pm 0.06^{*}$ & $5.2 \pm 0.07^{\star}$ \\
\hline
\end{tabular}

Values are mean \pm SEM; $n=6 ;{ }^{*} P<0.001 ;{ }^{* *} P<0.01 ;{ }^{* *} P<0.05$ compared with positive control. RBC: Red blood cell; SEM: Standard error mean; Hb: Hemoglobin; WBC: White blood cell

compared to Group-II (+ve control) rodents. The results are tabulated in Table 4.

\section{Prominence of ethanolic extract of Cordia sebestena fruit on serum electrolytes}

The results in Table 5 signified the variations in serum electrolytes level of diabetic rodents treated for 21 days with EECSF 100 and $200 \mathrm{mg} / \mathrm{kg}$ and glibenclamide $0.6 \mathrm{mg} / \mathrm{kg}$, body weight. The concentrations of all the estimated electrolytes were diminished in Group-II rodents except for $\mathrm{Cl}^{-}$as compared to Group-I. The treatment with EECSF at $100 \mathrm{mg} / \mathrm{kg}$ significantly $(P<0.001)$ ameliorated altered concentrations of all the estimated electrolytes. EECSF at $200 \mathrm{mg} / \mathrm{kg}$ and glibenclamide significantly $(P<0.001)$ maintained the levels of electrolytes to conventional framework.
Precedence of ethanolic extract of Cordia sebestena fruit on hematological indices

The results in Table 6 explicated that the significant reduction in the levels of $\mathrm{RBC}$ and $\mathrm{Hb}$ was noticed in Group-II rodents, whereas the levels of WBC, lymphocytes, neutrophils, eosinophils, and monocytes were inflated. EECSF at $200 \mathrm{mg} / \mathrm{kg}$ significantly elevated the levels of RBC and $\mathrm{Hb}$ to approximately mainstream range and the elevated levels of WBC, lymphocytes, neutrophils, eosinophils, and monocytes were significantly reduced and maintained to near-normal.

\section{DISCUSSION}

The emergence of diabetes and liver disease is augmenting around the globe. The alliance between diabetes and liver disease is influential to diabetologist, hepatologist, and physicians. There are multiple hepatic diseases integrated to diabetes such as nonalcoholic fatty liver disease, 
cholelithiasis, cholecystitis, hepatitis, cirrhosis, and hemochromatosis and other liver diseases. ${ }^{16}$ A prodigious extension in the consumption of herbal medicaments has been inspected in the past 30 years. The World Health Organization determined that $80 \%$ of the world population living in developing countries depends on herbal medicinal products. ${ }^{9,17}$ Hence, the present study was proposed the estimate the antidiabetic outcome of $C$. sebestena fruit extract.

Pancreatic $\beta$-cells via the glucose transporter 2 acquire STZ where it results in necrosis by DNA interruption. Finally, pancreatic $\beta$-cell necrosis results in depredation in insulin release, causing elevation in blood glucose level. ${ }^{2}$ To inspect the antidiabetic outcome of EECSF, the biological study was performed for 21 days and the outcome affirmed that EESCF accommodates antidiabetic potential in dose-dependent manner. The significant antidiabetic outcome was observed at a dose of $200 \mathrm{mg} / \mathrm{kg}$ of EECSF as compared to glibenclamide-treated rodents.

Diabetes intensifies hepatic glucose constriction. It is evidenced that diabetes promotes serum activity levels of liver enzymes such as ALT, AST, and ALP. All these enzymes are present in multiple organs of the human body however are prominent in liver; elevated levels of these liver marker enzymes are noticed in hepatitis, cirrhosis, jaundice, and other hepatic dysfunctions. Similarly, bilirubin is an excretory product of hem, which is produced from oxidation of biliverdin and is among the key factors to estimate the liver function. Liver is responsible for conjugation of bilirubin with glucuronic acid to produce water-soluble derivative acceptable for excretion through bile, and extension in bilirubin level is an evidence of liver dysfunction. Similarly, declination in total protein levels may accord to impediment of oxidative phosphorylation process that result in depletion of protein absorption, reduction in protein synthesis, and an elevation in catabolic process. All these indicators reflected the hepatocytes disfigurement in STZ-induced diabetic rodents. ${ }^{3,18-21}$ To investigate the outcome of EECSF on liver function distortion associated with diabetes, serum assessment of ALT, AST, ALP, bilirubin, and TP was accomplished and results expressed that EECSF at $200 \mathrm{mg} / \mathrm{kg}$ remarkably reforms the levels to normal parameter in diabetic rodents representing hepatoprotective efficacy of EECSF.

Electrolytes in the serum are crucial in metabolic activities, systematic operation of cells and enzymes, and concentration gradient. ${ }^{2}$ Alterations in their concentrations designate development of various diseases. Diabetic patients may experience disorganization of water, and electrolytes balance evolved from insulin inadequacy, hyperglycemia, and hyperketonemia. ${ }^{22}$ Diabetes mellitus causes hyperglycemia, finally resulted in cell dehydration and movement of $\mathrm{K}^{+}$ions into extracellular fluid (ECF). This process intensified the activity of parietal cells of distal and cortical collecting tubules, resulting in increased renal excretion of $\mathrm{K}^{+}$. However, glycosuria discovered in diabetes leads to excretion of abundant water, $\mathrm{Na}^{+}$, and $\mathrm{K}^{+}$in urine. Hence, it is evidenced that electrolytes and water loss associated with diabetes would result in loss of ECF, resulting in loss of $\mathrm{Na}^{+}$and $\mathrm{K}^{+}$concentration. ${ }^{23}$ The function of $\mathrm{Na}^{+} / \mathrm{K}^{+}$-ATPase, $\mathrm{Ca}^{2+} /$ $\mathrm{Mg}^{2+}$-ATPase, $\mathrm{Na}^{+} / \mathrm{Ca}^{2+}$ exchanger, and $\mathrm{Ca}^{2+}$ pump established in cell membrane, mitochondria, and endoplasmic reticulum has been diminished in hyperglycemia. It was also observed that diabetic ketoacidosis initiated promotion in the level of $\mathrm{Cl}^{-}$due to serum glucose generation via gluconeogenesis, glycogenolysis, ketogenesis, and ketoacidosis, resulting in blood acidification causing acid-base imbalance in body. Therefore, to balance it, $\mathrm{Cl}^{-}$level is increased in the body. ${ }^{24-26}$ However, in the present study, it was discovered that EECSF at 100 and $200 \mathrm{mg} / \mathrm{kg}$ amended the electrolyte imbalance significantly by increasing the diminished levels of $\mathrm{Na}^{+}, \mathrm{K}^{+}, \mathrm{Ca}^{2+}$ and reducing the level of $\mathrm{Cl}^{-}$in treated rodents.

Diabetes developed changes in multiple hematological parameters and immune system. However, toxicological studies discovered alterations in hematological indices after ingestion of medicinal plant extract or drugs. Hence, assessment of hematological indices is a vital tool in detecting deleterious effect of synthetic drugs and plant extracts. ${ }^{27}$ The depletion in $\mathrm{RBC}$ count is frequently affiliated to anemia, and its presence in diabetes can be affiliated with various factors such as glomerular filtration rate, urinary albumin excretion rate, and $\mathrm{HbAlc}$ levels. ${ }^{28}$ Anemia in diabetes is because of increased nonenzymatic glycosylation of RBC membrane protein, which correlates with hyperglycemia and oxidation of glycosylated membrane protein and hyperglycemia resulted in an increase in the development of lipid peroxidases leading to hemolysis. ${ }^{29} \mathrm{WBCs}$ are accountable for body defense against infections and it is familiar that reduced level of WBC in diabetes resulted in suppressed immune system..$^{30,31}$

In the current study, it was discovered that diabetic rodents represented unsettled blood indices. It was observed that animals in diabetic control group represented declined $\mathrm{RBC}$ and $\mathrm{Hb}$ levels as compared to normal and treated animals. The treatment with EECSF reconstructed the levels of RBC and its related indices, proclaiming that EECSF possessed few phytoconstituents that could elevate RBC and $\mathrm{Hb}$. Moreover, EECSF at 100 and $200 \mathrm{mg} / \mathrm{kg}$ ameliorated WBC count, lymphocytes, neutrophils, eosinophils, and monocytes levels, therefore contributing to its immunomodulatory effect.

\section{CONCLUSION}

The conclusion of the current research study is that $C$. sebestena fruit exhibited antidiabetic potential and maintained the level of various serum enzymes and biochemical parameters such as ALP, ALT, AST, TB, and TP which are altered in diabetes. The fruit extract maintained the level of serum electrolytes and hematological indices to normal in diabetic animals. Therefore, it can be recommended that $C$. sebestena fruit not only maintains normal blood glucose level rather has appreciable effect on various parameters that are disturbed in diabetes.

\section{ACKNOWLEDGMENT}

We are thankful to laboratory staff members at Moradabad Educational Trust, Group of Institutions, Faculty of Pharmacy, Moradabad, for their kind assistance.

\section{Financial support and sponsorship \\ Nil.}

\section{CONFLICTS OF INTEREST}

The authors declare no conflict of interest.

\section{REFERENCES}

1. Al-Jameil N, Khan FA, Arjumand S, Khan MF, Tabassum H. Associated liver enzymes with hyperlipidemic profile in type 2 diabetes patients. Int J Clin Exp Pathol 2014;7:4345-9.

2. Chaudhary S, Semwal A, Kumar H, Verma HC, Kumar A. In-vivo study for antihyperglycemic potential of aqueous extract of Basil seeds (Ocimum basilicum linn) and its influence on biochemical parameters, serum electrolytes and haematological indices. Biomed Pharmacother 2016;84:2008-13.

3. Ghanbari E, Nejati V, Khazaei M. Improvement in serum biochemical alterations and oxidative stress of liver and pancreas following use of royal jelly in streptozotocin-induced diabetic rats. Cell J 2016;18:362-70.

4. Simaraks S, Chinrasri O, Aengwanich W. Hematological, electrolyte and serum biochemical values of the Thai indigenous chickens (Gallus domesticus) in northeastern, Thailand. Songklanakarin J Sci Technol 2004;26:425-30.

5. Ergul A, Kelly-Cobbs A, Abdalla M, Fagan SC. Cerebrovascular complications of diabetes: Focus on stroke. Endocr Metab Immune Disord Drug Targets 2012;12:148-58

6. Konstantinov NK, Sun Y, Vigil D, Agaba El, Servilla KS, Murata GH, et al. Hyperkalemia in two patients with diabetes mellitus and chronic kidney disease and the role of disrupted internal potassium balance. Cureus 2014;6:1-16. 
7. Tolman KG, Fonseca V, Dalpiaz A, Tan MH. Spectrum of liver disease in type 2 diabetes and management of patients with diabetes and liver disease. Diabetes Care 2007;30:734-43

8. Rafe MR. A review of five traditionally used anti-diabetic plants of Bangladesh and their pharmacological activities. Asian Pac J Trop Med 2017; 10:933-9.

9. Al-Shaqha WM, Khan M, Salam N, Azzi A, Chaudhary AA. Anti-diabetic potential of Catharanthus roseus linn. And its effect on the glucose transport gene (GLUT-2 and GLUT-4) in streptozotocin induced diabetic wistar rats. BMC Complement Altern Med 2015;15:379

10. Dai J, Sorribas A, Yoshida WY, Williams PG. Sebestenoids A-D, BACE1 inhibitors from Cordia sebestena. Phytochemistry 2010;71:2168-73.

11. Oza MJ, Kulkarni YA. Traditional uses, phytochemistry and pharmacology of the medicinal species of the genus cordia (Boraginaceae). J Pharm Pharmacol 2017;69:755-89

12. Chaudhary S, Gupta RK, Kumar A, Tarazi H. Hepatoprotective and antioxidant potential of Nyctanthes arbor-tristis L. leaves against antitubercular drugs induced hepatotoxicity. J Pharm Pharmacogn Res 2018;6:205-15.

13. Joy KL, Kuttan R. Anti-diabetic activity of Picrorrhiza kurroa extract. J Ethnopharmacol 1999;67:143-8.

14. Lowry OH, Rosebrough NJ, Farr AL, Randall RJ. Protein measurement with the folin phenol reagent. J Biol Chem 1951;193:265-75.

15. Onunogbo CC, Ohaeri OC, Eleazu CO. Effect of mistletoe (Viscum album) extract on the blood glucose, liver enzymes and electrolyte balance in alloxan induced diabetic rats. Am J Biochem Mol Biol 2013;3:143-50.

16. Ahmed $\mathrm{MH}$, Husain NE, Almobarak AO. Nonalcoholic fatty liver disease and risk of diabetes and cardiovascular disease: What is important for primary care physicians? J Family Med Prim Care 2015;4:45-52

17. Ekor M. The growing use of herbal medicines: Issues relating to adverse reactions and challenges in monitoring safety. Front Pharmacol 2014;4:177.

18. Jayant SK, Srivastava N. Effect of Ocimum sanctum against alloxan induced diabetes and biochemical alterations in rats. Integr Obesity Diabetes 2016;2:1-4.

19. Ogunlana OO, Ogunlana OE, Ugochukwu SK, Adeyemi AO. Assessment of the ameliorative effect of ruzu herbal bitters on the biochemical and antioxidant abnormalities induced by high fat diet in wistar rats. Int $\mathrm{J}$ Pharmacol 2018;14:329-41.

20. Ozougwu JC. Physiology of the liver. Int J Res Pharm Biosci 2017;4:13-24.

21. Prakasam A, Sethupathy S, Pugalendi KV. Influence of Casearia esculenta root extract on protein metabolism and marker enzymes in streptozotocin-induced diabetic rats. Pol J Pharmacol 2004;56:587-93.

22. Sunmonu TO, Afolayan AJ. Evaluation of antidiabetic activity and associated toxicity of Artemisia afra aqueous extract in wistar rats. Evid Based Complement Alternat Med 2013;2013:929074.

23. Hasona NA, Elasbali A. Evaluation of electrolytes imbalance and dyslipidemia in diabetic patients. Med Sci (Basel) 2016;4. pii: E7.

24. Shahid SM, Rafique R, MahboobT. Electrolytes and sodium transport mechanism in diabetes mellitus. Pak J Pharm Sci 2005;18:6-10.

25. Obafemi TO, Akinmoladun AC, Olaleye MT, Adesanya TA, Onasanya A, Onikanni SA. Amelioration of hematological and electrolyte imbalances in type 2 diabetic rats by methanolic and flavonoid-rich leaf extracts of Synsepalum dulcificum. Int J Toxicol Pharmacol Res 2016:8:326-31.

26. Kaplan JH. Biochemistry of Na,K-ATPase. Annu Rev Biochem 2002;71:511-35.

27. Osigwe CC, Akah PA, Nworu CS. Biochemical and haematological effects of the leaf extract of Newbouldia laevis in alloxan-induced diabetic rats. J Biosci Med 2017:5:18-36.

28. Erukainure OL, Ebuehi OA, Adeboyejo FO, Aliyu M, Elemo GN. Hematological and biochemical changes in diabetic rats fed with fiber-enriched cake. J Acute Med 2013;3:39-44

29. Olayaki LA, Ajibade KS, Gesua SS, Soladoye AO. Effect of Zingiber officinale on some hematologic values in alloxan-induced diabetic rats. Pharm Biol 2007; $45: 556-9$

30. Palacios I, Lozano M, Moro C, Arrigo MD, Rostagno MA, Martinez JA, et al. Antioxidant properties of phenolic compounds occurring in edible mushrooms. Food Chem 2011;128:674-8

31. Egunyomi A, Moody JO, Eletu OM. Antisickling activities of two ethno medicinal plant recipes used for the management of sickle cell anaemia in Ibadan, Nigeria. Afr J Biotechnol 2009;8:20-5.

\section{GRAPHICAL ABSTRACT}

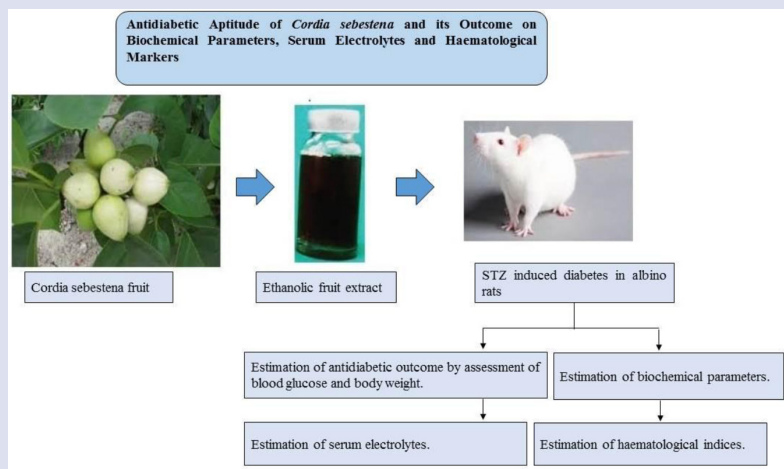

\section{SUMMARY}

- The antidiabetic effect of Cordia sebestena fruit was investigated against streptozotocin-induced diabetes in rats. The study also includes the effect of fruit extract on the levels of biochemical parameters, serum electrolytes, and hematological markers in diabetic rats.

\section{ABOUT AUTHORS}

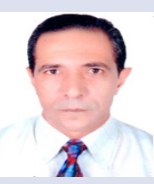

Professor Abdel-Nasser Ahmed El-Shorbagi, is currently working at Department of Medicinal Chemistry, College of Pharmacy, University of Sharjah, United Arab Emirates. He is specialist in medicinal chemistry, covering drug design and development, structure elucidation and biological investigation of natural phytochemicals, and their semi-synthesis as drug candidates.

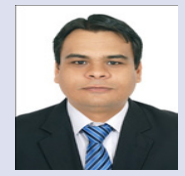

Dr. Sachin Chaudhary, Presently working at Department of Medicinal Chemistry, College of Pharmacy, University of Sharjah, United Arab Emirates. His area of research interest is investigation of natural phytochemicals, synthetic medicinal chemistry, drug design and discovery.

Cite this article: Chaudhary S, Verma HC, Gupta MK, Kumar H, Swain SR, Gupta RK, et al. Antidiabetic aptitude of Cordia sebestena and its outcome on biochemical parameters, serum electrolytes, and hematological markers. Pharmacog J. 2019;11(2):418-23 